\title{
Design Thinking in Classroom: An Experience with Undergrad Students of a Business Course
}

\author{
Hong Yuh Ching ${ }^{1}$ \\ ${ }^{1}$ Business School, Centro Universitário da FEI, São Bernardo do Campo, Brazil \\ Correspondence: Centro Universitário da FEI, Av. Humberto de Alencar Castelo Branco, 3972, 09850-901, São \\ Bernardo do Campo, Brazil. Tel: 55-11-4353 2900. E-mail: hongching@fei.edu.br
}

Received: May 23, 2014

Accepted: June 15, 2014

Online Published: June 19, 2014

doi:10.5430/bmr.v3n2p110

URL: http://dx.doi.org/10.5430/bmr.v3n2p110

\begin{abstract}
As managers become more interested in design methods, business students will need to develop competency and business schools will, in turn, be expected to provide courses in these approaches. The objective of this paper is to describe the design thinking process of a learning situation project proposed to students of an undergrad course of Business at a Brazilian university. The project was to elevate the students' engagement and have them more motivated and fascinated in the classroom. This research is theoretical-empirical with descriptive objective. The reference used was the five phases of design thinking for educators. The contribution of this article is to fill the vacuum that exists in the academic study concerning the application of design thinking in the classroom. Helping the students to think like designers may prepare them to face challenges and to solve problems in school as well as in their professional lives.
\end{abstract}

Keywords: Design thinking, Classroom research, Undergrad students, Business course, Business education

\section{Introduction}

It is a common understanding that to be competitive in this technological and globalized world, it will require from corporations different strategies and constant innovation and from employees a different set of problem-solving skills than used and required in the past. For Shute and Becker (2010), one of those skills is known as Design Thinking DT. When you research DT online, you will quickly recognise that some people refer to the term as a kind of "meme" and why it is one of the more recent and commonly used buzz words in the design community (Waloszek, 2012). It became our daily routine to (re-) design our homes, our identities, our personal communication skills, our appearance as well as our furnishings, gardens or cities. Design seems to have changed from being a dedicated competence of professions in an industrialized economy, to something everybody can practice as part of the daily activities.

The wider understanding of the design concept originated approximately in the sixties (Wirtschaftspsychologie-aktuell, 2012). Originally used in the domains of architects, city planners, and designers of all stripes, it is now increasingly embraced by businesses and schools as part of what might be called the 21 st century "innovation and creativity agenda" (Bostwick, 2012). By that time designers, engineers and scientists had been focused on to disassemble large and complex problems into smaller tasks, to develop solutions and to add them later to an overall together. Johansson-Sköldberg, Woodilla and Çentinkaya (2013) argue that, when design thinking started as an academic area in the 1970s, it was taught by designers aiming to help management scholars and practitioners understand what design is and why it is relevant.

Rather than asking designers to make an already developed idea more attractive to consumers, companies are asking them to create ideas that better meet consumers' needs and desires. The former role is tactical and results in limited value creation; the latter is strategic and leads to dramatic new forms of value (Brown, 2008).

Design was always an incentive factor for product or service innovation process developments. But over the last decade, with several publications about Design Thinking (Brown, 2011; Razzouk \& Shute, 2012; Beckman \& Barry, 2007) and the establishment of special interest in social media, DT has gained attractiveness in business and became a label for the awareness that all kind of businesses and organisations can benefit from the designers way of thinking and working.

Design thinking has become an integral part of the design and engineering fields as well as business. It can also have a positive influence on $21^{\text {st }}$ century education across disciplines because it involves creative thinking in generating 
solutions for problems (Razzousk \& Shute, 2012). Students are required to read critically, think and reason logically, and solve complex problems. The fact that teachers are using human-centered design techniques to understand their students better makes students feel more engaged in the changing learning environment (IDEO, 2012).

The idea of applying design thinking an approach to management is new and, as yet, largely underdeveloped (Dunne $\&$ Martin, 2006). For them, what has implications for managers ultimately will affect business schools. As managers become more interested in design methods, business students will need to develop competency and business schools will, in turn, be expected to provide courses in these approaches. There is little or no evidence that design thinking is currently integrated into the learning process anywhere within the typical undergraduate college curriculum (DBL, 2014).

\subsection{Research Problem}

The problem this paper intends to address is: "how could the students redesign the classes to elevate their engagement and have them more motivated and fascinated in the classroom?"

\subsection{Contribution of this article}

The majority of the studies on design thinking that Razzouk and Shute (2012) reviewed in their paper aimed to examine the differences between novice and expert designers or characterize expert behaviour in the design process. They could neither find experimental evidence or empirical work in their literature review nor provide concrete examples of how and where design thinking would fit in the curriculum. The contribution of this article is to fill the vacuum that exists in the academic study concerning the application of design thinking in the classroom.

\subsection{Objective}

The objective of this paper is to describe the design thinking process of a learning situation project proposed to students of an undergrad course of Business at a Brazilian university. The project was to elevate the students' engagement and have them more motivated and fascinated in the classroom.

\section{Research Methodology}

This research is theoretical-empirical with descriptive objective due to its objective. The approach adopted is qualitative and the procedure is a single case study. A literature research was made in order to find related documents and articles on Design Thinking. Nevertheless, the research was mostly based on articles, academic papers and webpages.

A second part of the research was interaction with the students. The target population of this study was students from an undergrad course of Business at a Brazilian university in the state of São Paulo that attended the class "Entrepreneurship". The students, in a total of 36, were divided in 6 groups and they developed a project to tackle a challenge: how might they could redesign the classes to elevate their engagement and have them more motivated and fascinated in the classroom? The data collection were the reports provided by the students at the end of this assignment and the notes taken by the researcher in the students' group meetings.

This challenge came up after a survey made in the previous semester with a larger sample of students of this Business course. The reason of this survey was the fact that many students were failing in several disciplines throughout the eight semesters of the course and occasionally, more than once in the same discipline. Among the reasons of these failures, the top four were:

- Not enough time to study during the week (note: most of them work during the daytime);

- Low participation in class discussions;

- $\quad$ Boring classes with little innovation;

- Teaching methodologies were rated as old fashioned

The last two reasons are part of the same issue and form the challenge put to the students to solve using design thinking.

Every design process begins with a specific and intentional problem to address, this is called a design challenge. Understand the problem is crucial and the designers should know what the client really wants. However, in the case of this paper, the designers are ultimately "the clients", i.e., the students. Ideally, they should not be, but this was the decision taken by the researcher. Rather than a group of professors consulting the students and designing prototypes to this challenge, the researcher thought that the prototypes would have more adherence and legitimacy if proposed by the students themselves. 


\section{Literature review}

This section is divided in two parts. The first deals with the different definitions and meanings of design thinking while the second deals with the phases or steps in design thinking process.

\subsection{Definitions and meanings of design thinking}

Brown (2008) defines design thinking as a methodology that imbues the full spectrum of innovation activities with a human-centered design ethos. Put simply, it is a discipline that uses the designer's sensibility and methods to match people's needs with what is technologically feasible and what a viable business strategy can convert into customer value and market opportunity. Design thinking DT is a mindset, is about believing we can make a difference, and having an intentional process in order to get to new, relevant solutions that create positive impact (IDEO, 2012). For Dym, Agogino, Eris, Frey and Leifer (2005), design thinking reflects the complex processes of inquiry and learning that designers perform in a systems context, making decisions they proceed and often working collaboratively on teams in a social process. Dunne and Martin (2006) state that DT is the way designers think and it results from the nature of design work: a project based work flow around wicked problems. Finally, for Johansson-Sköldberg et al (2013) DT is a simplified version of 'designerly thinking' or a new way of describing a designer's methods that is integrated into an academic or practical management discourse.

Surely, there is not a universal accepted definiton of design thinking. What is common in these definitions is that DT is about innovation, collaboration with people and generating solutions regardless if these are objects, services ou systems.

Johansson-Sköldberg et al (2013) do not believe there is a unique meaning of design thinking. Instead they look for where and how the concept is used in different situations. They have identified multiple discourses with distinctly different meanings: five designerly discourses grounded within the design research area, and three discourses within the managerial area. For them, there are few links between them, the designerly thinking and design thinking.

Kimbell (2009) introduces a pair of ideas or concepts as an alternative to design thinking - design-as-practice and designs-in-pratice. These new concepts move the unit of analysis away from the individual designer, or the organization or group and its norms, to a wider frame which refocuses the research agenda. Design-as-practice mobilizes a way of thinking about the work of designing and offers rich resources for understanding what goes on during design activities and relating them to organizational outcomes (Kimbell, 2009). On the other hand, the term designs-in-pratice acknowledges the emergent nature of design outcomes as they are enacted in practice (Kimbell, 2009).

Despite the different meanings and concepts of design thinking displayed above, the ultimate goal of DT is to apply a creative, non - linear and interactive way of thinking and in particular a special process methodology for new ideas and to solve problems occurring in business every day, as it is systematically used in processes of product design and product development (Dym et al, 2005). The concept of design thinking became a portal for the whole design area to contibute to innovation (Johansson-Sköldberg et al, 2013).

Additionally Design Thinking assumes that innovations are created in a company less by individual ideas or singular works, but mostly by systematic design creativity in a team process which can include external customers and expertise opinions. People from different disciplines come together to ensure a variety of possible approaches for a problem of a Design Thinking project. This can be differentiated by profession, but also through cultural aspects, national or just age and gender differences. What counts is the multi-layered look at the specific topic (Hüttebräuker, 2013).

\subsection{Design thinking process}

The design process is what puts Design Thinking into action. It's a structured approach to generating and evolving ideas. It has five phases that help navigate the development from identifying a design challenge to finding and building a solution (IDEO, 2012). It is a deeply human approach that relies on your ability to be intuitive, to interpret what you observe and to develop ideas that are emotionally meaningful to those you are designing for - all skills you are well versed in as an educator (IDEO, 2012). For IDEO, the five phases are the following (see figure 1): 


\section{The alesign process is what puts Design Ihin king into action.}

It's a structured approach to generating and developing ideas.

\section{The five phases of the design process:}

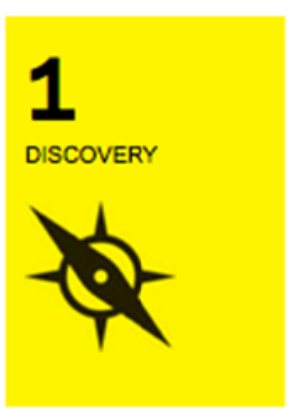

I have a challenge.

How do I approach it?
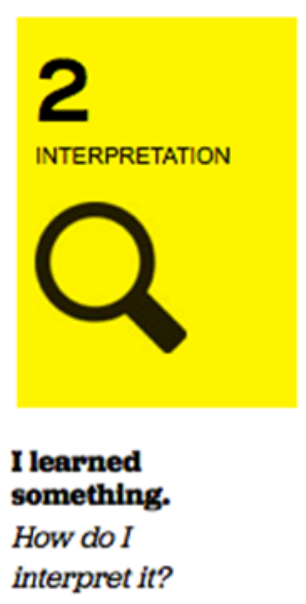

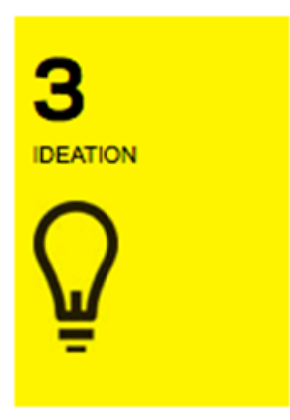

\section{I see an opportunity. What do Icreate?}

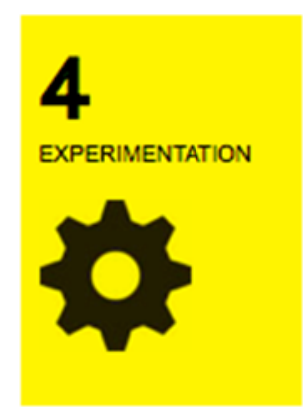

$\begin{array}{ll}\begin{array}{l}\text { I have an } \\ \text { idea. }\end{array} & \begin{array}{l}\text { I tried } \\ \text { something. }\end{array} \\ \text { How do I } & \text { How do I } \\ \text { build it? } & \text { evolve it? }\end{array}$

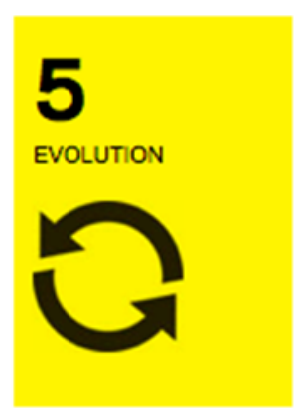

I tried How do I

Figure 1. The Design Thinking process (IDEO, 2012)

The problem definition and understanding (Discovery): Discovery builds a solid foundation for the ideas. It starts with understanding the challenge, a clearly defined challenge will guide the questions and help stay on track throughout the process (IDEO, 2012). It continues with preparing research, plan activities to learn from multiple peoples' perspectives and explore unfamiliar contexts and finishes with gathering information with a curious mindset. The idea is to wander in all directions. The real work begins in direct contact with the future users, consumers or customers. Those get interviewed and observed. Of course, everything is well documented, not only on paper but also with meaningful pictures, graphs, videos or voice recordings. Thinking in images is important and should be applied throughout the process. It increases the chance of being able to recall the information itself. Speaking, writing, drawing and gestures are in the combination of the ideal instruments to stimulate your own thinking process.

Observation (Interpretation): It involves storytelling, as well as sorting and condensing thoughts until you have found a compelling point of view and clear direction for ideation (IDEO, 2012). It starts with collecting, telling and sharing stories from your fieldwork. Begin to make sense of all that information and inspiration to identify themes, make sense of the findings and define insights. Finally, frame opportunities by creating a visual reminder, use visuals to make complex information more accessible and turn the insights as inspiring opportunities (IDEO, 2012).

Generating of Ideas (Ideation): This phase is one of the core elements of design thinking and consists mainly of brainstorming and its rules. Prepare initially for brainstorming and facilitate promising ideas. Brainstorming may often be thought of as wild and unstructured, but it in fact is a focused activity that involves a lot of discipline (IDEO, 2012). Take the time to set up appropriately in order to get the most out of this session. You then move to refine ideas by doing a reality check, look at what is most important about your idea and find ways to evolve and develop it further (IDEO, 2012).

Prototyping (Experimentation): Experimentation brings the ideas to life. Building prototypes means making ideas tangible, learning while building them and sharing them with other people (IDEO, 2012). Prototypes enable you to share your idea with other people and discuss how to further refine it. The next step is to get feedback. The ideas should then be made visible and communicable to help users to test them and to provide useful feedback. Every kind of prototype is better than a weak description. 
Testing and Optimization (Evolution): Evolution is the development of your concept over time. It involves planning next steps, communicating the idea to people who can help you realize it, and documenting the process. Track learning by defining a set of criteria for success and documenting the progress (IDEO, 2012). Then move forward, planning the next step and engaging others onboard. With your colleagues and team, create a timeline for bringing the concept to life.

Very important is that the Design Thinking process is based on iteration, going back to earlier steps. So the perceptions often result from the fifth phase, for example, back to the fourth, to construct a further improved prototype. To repeat a phase is not a loss of time and effort but knowledge and can therefore be treated as gain of learning success.

Other authors visualized design thinking in steps, processes or themes. Klotz's vision (2013) of design thinking is of six steps: understanding, watch, define view, find ideas, prototyping and testing. The first step involves defining the problem of the target group, while the watch steps grapples directly with the target group by interviewing users and asking how to solve a problem. These two steps are equivalent to discovery phase of IDEO process. The steps define view and find ideas involve developing insights and using brainstorming respectively and are similar to ideaton phase of IDEO. And finally, the last two steps, the prototyping and testing, are equivalent to experimentation and evolution phases.

Kolodner and Wills (1996) mentioned three processes required in design thinking: preparation, assimilation and strategic control. The first process is equivalent to the first two phases of IDEO where the designers need to learn what to focus on and what is relevant. The second process is equivalent to the third and fourth phases of IDEO, in which it involves making sense of the proposed solutions, data and observations coming from the design environment. Finally the strategic control process deals with the decisions over the course of a design. This can be related to the improvement and refinement of the prototype.

Similarly, Bostwick (2012) talks about three key themes in the design thinking process: exploration, idea generation and prototyping. The first theme is equivalent to the first two phases of IDEO; the second and third themes are identical to Ideation and Experimentation phases of IDEO respectively. The last phase of IDEO, the Evolution, does not find correspondence in Bostwick vision.

\section{Results and Discussion}

This section shows the experience of six groups in the class with the use of design thinking in the first semester of 2014. Prior to this assignment, the teacher gave two lessons explaining the concept, illustrated with some examples and videos and went through the five phases of design thinking for educators' material. Then, he introduced the challenge to the students.

In the first phase of Discovery, the designer should be broadly enough to allow for unexpected possibilities but narrowly enough to let him focus (IDEO, 2012).

All six groups basically interviewed and visited students, colleagues of other semesters from the same course, colleagues of other courses from the same university (engineering and computer science), colleagues of Business course from other universities and students of high school. They were looking for similar experiences during these interviews and visits in order to get inspiration for their assignment. A sample of the material produced by the groups can be summarized in the table 1 .

Table 1. motivators and demotivators for the students

\begin{tabular}{ll}
\hline Motivators & Demotivators \\
\hline Team work & Overwork \\
Feedback and opportunity to evolve & Professors demotivated \\
Good didactic & Lack of recognition \\
Interaction professor / student & Excess of content \\
Dynamic classes & Lack of practical exercises \\
Professors motivated & Lack of teamwork assignments \\
Merit recognition & Boring classes \\
Visit to companies & Lack of feedback and incentives \\
\hline
\end{tabular}


Discovery means opening up to new opportunities and getting inspired to create new ideas. In IDEO's material (2012), a team from a school, looking to design new ways for teachers to collaborate, decided to visit analogous settings where collaboration happens, such as fire station, corporate office and a design studio. This can be the criticism made to the six groups. They did not open up their vision looking for different scenarios other than academic environment. Moreover, they spent a reasonable amount of time defining more precisely the problem and how to tackle it and hindering their progress in the next phase. This finding is similar to Gunther and Ehrlenspiel study (1999) that conducted a set of experiments with novice and expert designers of mechanical devices and found that novices spent more time defining the problem.

The second phase, of Interpretation, transforms the ideas into meaningful insights and turns them into actionable opportunities for design (IDEO, 2012). This phase was divided in two sub phases. Initially, the students should find meaning in all the material they collected in the previous phase. They should organize stories from field research into categories. They did this in their own separate groups. Then, they were asked to group together into a single big group. They were asked by the researcher to create themes from their categories. They are the headlines for clusters of similar learnings. What were the patterns and/or themes they could envisage and list them as opportunities for design? They were grouped in six themes:

Technology

Classroom layout

Teaching methodologies

Reward and incentives

Outside professionals

Miscellaneous

This phase is similar to the stage of Framework in Beckman and Barry study (2007). Armed with the data generated from the observation stage (in our case, the Discovery phase), the innovation process moves from the concrete to the abstract realm, attempting to make sense of the data that was collected, framing that data to identify patterns.

In the next phase, the Ideation, the students, assembled in a single group, were instructed by the researcher to the brainstorm rules. The purpose of assembling them together is the more heads thinking, the more ideas will come up. The rules were the following (IDEO, 2012):

- Defer judgment. There are no bad ideas at this point, the time for narrow them down is the next phase.

- Encourage wild ideas. Even if an idea does not seem realistic, it may spark a great idea for someone else.

- Build on the ideas of others. Think "and" rather than "but".

- One conversation at a time. All ideas need to be heard, so that they may be built upon.

- Be visual. Draw your ideas, as opposed to just writing them down.

- Go for quantity. Set an outrageous goal- then surpass it. The best way to find one good idea is to come up with lots of ideas (IDEO, 2012). 
The table 2 shows an extract of the ideas presented in the brainstorm session.

Table 2. Brainstorm ideas

\begin{tabular}{ll}
\hline Themes & Ideas \\
\hline Technology & - use of personal computers in the classroom \\
& - on line platform more user friendly (note: currently this university is using moodle) \\
& - classes of maths, statistics and finance in the IT lab \\
& - on line classes with chats for exercises, to post videos, Q\&A sessions \\
& (note: this university has wi-fi in the whole campus) \\
Classroom & - "U" shape classrooms \\
& - classes outside the classroom in an open environment to take advantage of the campus \\
& infrastructure \\
& - use of music in the classroom in some practical classes \\
Teaching & - classes with groups interacting with each other to solve a specific challenge \\
methodologies & - games and competitions across the classes in a common theme or assignment \\
& - more time reserved between professors and students for dialogue and interaction \\
& - more active participation of the students in the classes as opposed to lecture classes by the \\
& professors (e.g. debates, simulations) \\
& - role playing of real situations such as job interviews, pitch fights etc
\end{tabular}

Reward and - offer bonus for participative debates rather than "forcing" students to read and write incentives compulsory essays

- reward for the best business plan of the semester

- assessment methods and criteria more diversified based on competences as opposed to knowledge

Outside - visit to environments that add experience, culture and knowledge, like Stock Exchange, professionals Historical museums etc

and visits - visit to companies to discuss in loco their marketing campaigns and/or to see their manufacturing processes

- speechs given by external businessmen, consultants and entrepreneurs to report their experiences

Miscellaneous - social events between faculty and students, like barbecues

- introduction of major disciplines in the last semesters of the course - charity contest to raise donations

The fourth phase, the Experimentation, is to make ideas tangible into prototypes. It was also divided in two sub-phases. The students were broken up again in their original teams and were given paper, post-it, scissors, card boards, pens and sheets of paper. They were instructed to use a lot of imagination and have fun. They will be amazed at how much they could learn about the idea just in the process of building it out (IDEO, 2012).

One of the groups called the researcher attention because of the use of storyboard. This concept was not given in class and this group found out about its use by researching in the internet. It can be defined as a panel or series of panels of rough sketches outlining the scene sequence and major changes of action or plot in a production to be shot on film or video (The free dictionary, 2014). Together with the storyboard, the group produced a digital material with animation images to illustrate their prototypes.

The next sub-phase was to get feedback. Feedback is one of the most valuable tools in developing an idea (IDEO, 2012). The groups were brought back into a single group to share their prototypes. This helps them to see what really matters as students and which aspects need improvement. Each group presented the development of their ideas and clarified those aspects that were most appealing and/or difficult. The feedback helped them understand what felt engaging to themselves as students, so that they could continue to refine the ideas. Yet, some of the ideas were dropped because of money needed to invest and the length of timeframe estimated to implement.

The researcher did not intervene nor participate in this phase, he just kept taking notes of the debates amongst the students. Three of the prototypes can be illustrated in figure 2 . 


\begin{tabular}{|c|c|c|}
\hline Ideation & Methodology & Expected result \\
\hline Layout in "U" shape & $\begin{array}{l}\text { Place the chairs in "U" shape } \\
\text { before the class starts so that } \\
\text { students are side facing each } \\
\text { other and those at the back of the } \\
\text { room face the blackboard. The } \\
\text { teacher stays at the center of "U" } \\
\text { shape }\end{array}$ & $\begin{array}{cc}\checkmark \quad \text { More interaction student/ } \\
\text { professor; } \\
\checkmark \quad \text { Students will be more } \\
\text { concentrated; } \\
\checkmark \quad \text { No side talks; } \\
\checkmark \quad \text { Mood of the classroom more } \\
\text { pleasant; } \\
\checkmark \quad \text { Incentives students to debate. }\end{array}$ \\
\hline Ideation & Methodology & Expected result \\
\hline $\begin{array}{c}\text { Lecture classes mixed with } \\
\text { pratical ones } \\
\text { (exercises/case studies) }\end{array}$ & $\begin{array}{l}\text { After a brief lecture of a topic, the } \\
\text { teacher challenges students with a } \\
\text { practical exercise, business } \\
\text { situation or initiates a debate } \\
\text { about a case study. This business } \\
\text { situation or business case can be } \\
\text { brought by the students. }\end{array}$ & $\begin{array}{c}\checkmark \text { Better learning of the topic; } \\
\checkmark \text { Prompts tudents to do the } \\
\text { exercises; } \\
\checkmark \text { Students can identify } \\
\text { themselves in their daily } \\
\text { business issues or challenges } \\
\text { given in class. }\end{array}$ \\
\hline Ideation & Methodology & Expected result \\
\hline $\begin{array}{l}\text { Classes outside the classroom } \\
\text { in an open environment to } \\
\text { promote debates on topics } \\
\text { related to the discipline }\end{array}$ & $\begin{array}{l}\text { The students pick a topic or case of } \\
\text { the discipline and the place in the } \\
\text { campus to have the class. } \\
\text { The teacher books in advance this } \\
\text { place in the campus. }\end{array}$ & $\begin{array}{c}\checkmark \quad \text { More interaction and } \\
\text { participation from the } \\
\text { students; } \\
\checkmark \quad \text { Better assimilation of the topic. }\end{array}$ \\
\hline
\end{tabular}

Figure 2. prototypes

Prototypes produced by the other groups are shown as examples in table 3.

Table 3. other prototypes produced

\begin{tabular}{|c|c|c|}
\hline Product & Methodology & Result expected \\
\hline $\begin{array}{l}\text { Classes with } \\
\text { group } \\
\text { interactions }\end{array}$ & $\begin{array}{l}\text { On basis of existing business plans, each week one is selected and all } \\
\text { the students will be part of the same company and each group will be } \\
\text { playing a separate function (marketing, finance etc). The teacher will } \\
\text { present a problem that involves the whole company. The students, in } \\
\text { their separate functions, should work in synergy to propose a solution. } \\
\text { At the end, the teacher makes the comments on the proposals. }\end{array}$ & $\begin{array}{l}\text { More dynamic classes } \\
\text { Better interaction } \\
\text { between the students } \\
\text { Learning by doing } \\
\text { It will stimulate } \\
\text { students to debate } \\
\text { business issues }\end{array}$ \\
\hline & $\begin{array}{l}\text { A challenge is launched to all the students with specific duration for } \\
\text { each task of the contest. The objective is to raise donations for one or } \\
\text { more charity institutions. This can take several weekends. The } \\
\text { winning team will receive a bonus in the grade. }\end{array}$ & $\begin{array}{l}\text { Awareness of social } \\
\text { responsibility } \\
\text { Integration between } \\
\text { classes }\end{array}$ \\
\hline $\begin{array}{l}\text { External } \\
\text { professionals } \\
\text { participation }\end{array}$ & $\begin{array}{l}\text { External professional would be invited by the school or by the students } \\
\text { to debate or lecture about specific topics according to their area of } \\
\text { expertise. Example: business strategy class - an expert would explain } \\
\text { and illustrate how the strategies are applied by the organizations; a } \\
\text { marketing class - an expert in retail business would explain the } \\
\text { concept of ECR Efficient Consumer Response. } \\
\text { The theme or topic of the class would be agreed in common by the } \\
\text { faculty and students. }\end{array}$ & $\begin{array}{l}\text { Interaction of the } \\
\text { students with the } \\
\text { professional } \\
\text { Assimilation of the } \\
\text { concepts given in class } \\
\text { prior to the external } \\
\text { participation }\end{array}$ \\
\hline
\end{tabular}


For Brown (2008) prototypes of a service innovation will not be physical, but they must be tangible. The goal of prototype is not to finish. It is to learn about the strengths and weaknesses of the idea and to identify new directions that further prototypes might take.

In the final phase, the Evolution, the development of the prototypes over time, the students planned the next steps:

- The prototypes should be put in practice in one class for one semester and assigned a champion;

- Indicators should be identified to measure the progress and success, such as: a) have the teachers noticed change in the students' behaviour? b) has the relationship between the students and teachers changed?; c) have the grades improved?; d) have the classes become more involving?; e) did this new approaches help faculty do their job?;

- The experience should be shared with other audiences, outside this design team;

- More classes should be putting these prototypes in practice

At the end of this project, the students said they felt chaotic experiencing design thinking for the first time and had a lot of fun. But they also reckon, with more experience in designing, they would see that the design process makes sense and achieves results. They said they cannot think in a traditional way on the basis of what they already know or have seen before. Instead, they should think outside the existing alternatives, something completely new. These are inductive logic and abductive reasoning respectively (Dunne \& Martin, 2006). Finally, they also commented they could use DT in their business activities.

\section{Final Considerations}

There is a consistent set of challenges that teachers and schools seem to face, and they center around the design and development of learning experiences (curriculum), learning environments (spaces), school programs and experiences (processes and tools), and system strategies, goals and policies (systems) (IDEO, 2012). However, helping the students to think like designers may prepare them to face challenges and to solve problems in school as well as in their professional lives. Students benefit from having time to explore, ideate, experiment and revise across disciplines, while becoming attuned to needs below the surface (Bostwick, 2012).

For Razzouk and Shute (2012), by improving students' design thinking skills, through having them apply processes and methods that designers use to ideate, and help them experience how designers approach problems to try to solve them, students will be more ready to face problems and think outside the box.

The integrated innovation process as a learning model suggests that there should be cross-disciplinary teams and representation from each of the learning styles on the team, namely Diverging, Accommodating, Assimilating and Converging (Beckman \& Barry, 2007). This can be another criticism of this study in which students from other courses in this university could be doing this DT project, such as, computer science, production engineering, mechanical engineering, alongside the business course students.

On the other hand, Dunne and Martin (2006) advocate the addition of the design perspective to the current curriculum in the management education as both a new set of ideas and a way of integrating existing ones. Bostwick (2012) states that the incorporation of design thinking into curriculum is timely.

The conclusion is that no matter where we look, wee see challenges everywhere that can be solved through creativity and innovation and design thinking might be such an approach. As Brown mentioned (2008) these challenges or problems all have people at their heart. They require a human-centered, creative, iterative and practical approach to finding the best ideas and ultimate solutions. In fact, these are some of the characteristics that Owen (2006) nominated for design thinking, amongst others.

The limitation of this study was the short time devoted by the students to this project. Because they study in an evening course, they had Saturdays as spare time to do the project. It competed with other assignments and homework. This could have compromised the quantity and quality of the ideas and prototypes proposed. Suggestion for a future research is to test and refine the prototypes making a virtuous circle of prototyping, testing and refinement.

\section{Acknowledgement}

The author would like to thank Johannes Hesse, student from NHTV University of Applied Science Breda, Netherlands, who helped with some references in German language. 


\section{References}

Beckman, S. L., \& Barry, M. (2007). Innovation as a learning process: Embedding Design Thinking. California Management Review, 50 (1), 26-58. http://dx.doi.org/10.2307/41166415

Bostwick, L. (2012). Design thinking: an introduction. Independent Teacher Magazine. Retrieved from http://www.nais.org/Magazines-Newsletters/ITMagazine/Pages/Design-Thinking-An-Introduction.aspx

Brown, T. (2008). Design thinking. Harvard Business Review, June.

DBL Designing Better Libraries. (2014). Design thinking for our college students - a better higher education experience? WorldPress weblog. Retrieved from http://dbl.lishost.org/blog/2013/02/11/design-thinking-for-our-college-students-a-better-higher-education-experi ence/\#.U5ssHnYeeZQ

Dunne, D., \& Martin, R. (2006). Design thinking and how it will change management education; An Interview and Discussion. Academy of Management Learning \& Education, 5 (4), 412-523, http://dx.doi.org/10.5465/AMLE.2006.23473212

Dym, C., Agogino, A.M., Eris, O., Frey, D.D., \& Leifer, L.J. (2005). Engineering design thinking, teaching, and learning. Journal of Engineering Education, 103-120, http://dx.doi.org/10.1002/j.2168-9830.2005.tb00832.x

Gunther, J., \& Ehrlenspiel, K. (1999). Comparing designs from practice and designing with systematic design education. Design Studies, 20, 439-451, http://dx.doi.org/10.1016/S0142-694X(99)00019-8

Hüttebräuker, P. (2013). Design thinking - ein kurze einführung. Innovator's Guide. Retrieved from http://innovators-guide.ch/2013/02/design-thinking/.

IDEO. (2012). Design thinking for educators, 2nd edition. Retrieved from http://www.designthinkingforeducators.com.

Johansson-Sköldberg, U., Woodilla, J., \& Çentinkaya, M. (2013). Design thinking: past, present and possible futures. Creativity and Innovation Management, 22 (2), 121-146. http://dx.doi.org/10.1111/caim.12023

Kimbell, L. (2009). Beyond design thinking: design-as-practice and designs-in-practice. CRESC Centre for Research on Socio-Cultural Change Conference, Manchester, UK. Retrieved from http://www.design.org.br/artigos_cientificos/beyond_design_thinking.pdf

Klotz, M. (2013). Design thinking - mit methode zur innovation. T3N Digital Pioneers. Retrieved from http://t3n.de/news/design-thinking-6-schritten-507155/.

Kolodner, J., \& Wils, L. (1996). Power of observation in creative design. Design Studies, 17, 385-416, http://dx.doi.org/10.1016/S0142-694X(96)00021-X

Owen, C. (2006). Design thinking: Notes on its nature and use. Design Research Quarterly, 1 (2),16-27.

Razzouk, R., \& Shute, V. (2012). What is design thinking and why is it important? Review of Educational Research, 82 (3), 330-348, http://dx.doi.org/10.3102/0034654312457429

Shute, V.J., \& Becker, B.J.(2010). Innovative Assessment for 21st Century. New York: Springer. http://dx.doi.org/10.1007/978-1-4419-6530-1

The free dictionary. (2014, April 16). Retrieved from http://www.thefreedictionary.com/storyboard.

Waloszek, G. (2012). Introduction to design thinking. SAP. Retrieved from http://www.sapdesignguild.org/community/design/design_thinking.asp.

Wirtschaftspsychologie-aktuell. (2012). Strategie: Design Thinking. Retrieved from http://www.wirtschaftspsychologie-aktuell.de/strategie/strategie-20120427-design-thinking.html. 